\title{
Correction to: The coracoscapular joint of neornithine birds-extensive homoplasy in a widely neglected articular surface of the avian pectoral girdle and its possible functional correlates
}

\author{
Gerald Mayr ${ }^{1}$ (D)
}

Published online: 11 June 2021

๑) Springer-Verlag GmbH Germany, part of Springer Nature 2021

Correction to: Zoomorphology

https://doi.org/10.1007/s00435-021-00528-2

Unfortunately, Table 1 was incorrectly published in original version. The correct version is now updated.

The original article has been corrected.

Publisher's Note Springer Nature remains neutral with regard to jurisdictional claims in published maps and institutional affiliations.

The original article can be found online at https://doi.org/10.1007/ s00435-021-00528-2.

Gerald Mayr

Gerald.Mayr@senckenberg.de

1 Ornithological Section, Senckenberg Research Institute and Natural History Museum Frankfurt, Senckenberganlage 25, 60325 Frankfurt am Main, Germany 